\title{
Epidemiological characteristics of primary spinal osseous tumors in Eastern China
}

\author{
Zhenhua Zhou ${ }^{\dagger}$, Xudong Wang ${ }^{\dagger}$, Zhipeng Wu, Wending Huang and Jianru Xiao
}

\begin{abstract}
Background: Primary spinal osseous tumors are rare, yet they represent a difficult treatment paradigm because of the complexities of tumor resection and significant resistance to chemotherapy and radiation therapy. The geographic distribution of primary spinal osseous tumors throughout the world appears to be quite variable, with a very low incidence reported in Asian countries.

Methods: Data on 1209 cases of primary spinal osseous malignant and benign tumor cases diagnosed during the 20-year period of 1995 through 2015 in eastern China were analyzed.

Results: In 780 cases (64.5\%), the lesion was benign and in 429 (35.5\%) was malignant. The commonest primary malignant tumors were chordoma ( $9.8 \%$ of all cases) followed by plasma cell myeloma ( $8.5 \%$ of all cases). The most common benign tumor was hemangioma (28.1\% of all cases) followed by giant cell tumor of bone (15.7\% of all cases) and osteoblastoma (4.4\% of all cases). The benign tumors affected men in $33.8 \%$ of cases and women in $30.7 \%$ of cases, the malignant tumors affected men in $23.7 \%$ of cases and women in $11.8 \%$. The mean age (mean \pm SD) in the benign group was $34.7 \pm 19.8$ years and in the malignant group was $47.4 \pm 16.5$ years. Related symptoms were pain (54.4\%), radiculopathy (12.9\%), cord compression (9.2\%), mass (5.7\%), pathological fracture (4.7\%), deformity (2.1\%), and weight loss (1.9\%). The anatomical locations included almost every vertebra of the spine. The thoracic spine (38.1\%) was the most common location of the tumors, followed by the cervical spine (27.4\%) and lumbar spine (18.4\%).
\end{abstract}

Conclusions: Compared with other similar series reported in the literature from the other countries, our results obtained in a developing country were different in some degree. This large series of primary spinal osseous tumors may reflect fairly well their real incidence and provide a sufficiently detailed perspective on epidemiologic studies of primary spinal osseous tumors in eastern China.

Keywords: Spine, Primary osseous tumors, Epidemiology

\section{Background}

Primary spinal osseous tumors are uncommon; previous reports showed that spinal osseous tumors were comprising $6 \sim 10 \%$ of all bone tumors [1-5]. Little was known about the etiology of spine osseous tumors. Published case reports focused on spine neoplasm usually had a limited case number, and few reports described epidemiological characteristics of spine osseous tumors. However, it is important to understand the etiology of spinal osseous tumors and information regarding the epidemiology of primary spine osseous tumors.

\footnotetext{
*Correspondence: jianruxia063@126.com

${ }^{\dagger}$ Equal contributors

Department of Orthopaedic Oncology, Changzheng Hospital, The Second

Military Medical University, No.415, Fengyang Road, Shanghai 200003, China
}

The present study performed an epidemiological analysis of 1209 consecutive tumors of osseous spine registered in 3 collaborating state bone tumor database (Eastern China) between 1995 and 2015. To our knowledge, the present study is the first report of epidemiological data concerning spinal osseous tumors in Asian population. Our findings showed that epidemiological features of primary spinal osseous tumors in xanthoderm, with respect to relative frequency and distribution of the various histologic types, as well as the clinical data, and compare the results with other epidemiological findings from different geographic locations around the world, which could provide valuable clues for epidemiology of primary spine osseous tumors in Asian. 


\section{Methods}

\section{Data sources}

Data for this study were obtained from Bone Tumors and Nervous System Tumors Biobank of Shanghai (BT\&NSTBS), Bone Tumor Sample Databases and Digital Information Platform of Shanghai (BTSD\&DIPS), and Shanghai Biobank Network of Common Human Tumor Tissue (SBNCHTT). One thousand two hundred nine cases of spinal osseous tumors registered in abovementioned 3 database between 1995 and 2015 were selected for this study. Data collected for each patient included personal information such as name, age, sex, anatomical site of the tumor, and clinical and histological diagnoses. In the case of recurrent tumors, the histological appearance of the original and the recurrent tumors was compared and was considered as only one case. The diagnoses were re-evaluated according to the criteria suggested for the 2013 WHO histological classification [6].

\section{Statistics}

SPSS17.0 software (SPSS Inc., Chicago, IL) was used for statistical analysis of experimental data. Descriptive statistics was performed to calculate the frequency and percentages of variables mentioned before. Age was stratified into various groups at 10 -year intervals.

\section{Results}

The histological types of the spinal osseous tumors are listed in Table 1 and Fig. 1. Of these, 64.5\% (780 cases) were benign and $35.5 \%$ (429 cases) were malignant, The most common histological type of benign tumors was hemangioma accounting for $28.1 \%$ of all tumors (340 cases), followed by giant cell tumor (15.7\%; 190 cases),

Table 1 Frequency, age, and gender distribution of primary spine osseous tumors

\begin{tabular}{|c|c|c|c|c|c|c|c|c|c|c|c|}
\hline \multirow[t]{2}{*}{ Type of tumor } & \multicolumn{2}{|c|}{ Number (\%) } & \multicolumn{2}{|l|}{ Male } & \multicolumn{2}{|c|}{ Female } & \multirow{2}{*}{$\begin{array}{l}\text { Male vs } \\
\text { female }\end{array}$} & \multirow{2}{*}{$\begin{array}{l}\text { Age } \\
\text { range } \\
\text { (years) }\end{array}$} & \multicolumn{3}{|c|}{ Mean \pm SD (age) } \\
\hline & No. & $\%^{a}$ & No. & $\%^{a}$ & No. & $\%^{\mathrm{a}}$ & & & Male & Female & Total \\
\hline Benign tumors & 780 & 64.5 & 409 & 33.8 & 371 & 30.7 & 52.4 vs $47.6 \%$ & $9-79$ & $33.7 \pm 19.2$ & $35.9 \pm 20.6$ & $34.7 \pm 19.8$ \\
\hline Hemangioma & 340 & 28.1 & 174 & 14.4 & 166 & 13.7 & 51.2 vs $48.8 \%$ & $12-79$ & $47.1 \pm 14.3$ & $51.5 \pm 12.9$ & $49.2 \pm 13.7$ \\
\hline Giant cell tumor & 190 & 15.7 & 91 & 7.5 & 99 & 8.2 & 47.9 vs $52.1 \%$ & $15-66$ & $34.5 \pm 11.0$ & $32.9 \pm 12.1$ & $33.6 \pm 11.5$ \\
\hline Eosinophililc granuloma & 47 & 3.9 & 36 & 3.0 & 11 & 0.9 & 76.6 vs $23.4 \%$ & $10-56$ & $23.7 \pm 14.3$ & $29 \pm 17.6$ & $23.7 \pm 14.7$ \\
\hline Osteoblastoma & 53 & 4.4 & 28 & 2.3 & 25 & 2.1 & 52.8 vs $47.2 \%$ & $9-54$ & $32.6 \pm 10.5$ & $26.5 \pm 15.0$ & $28.7 \pm 13.2$ \\
\hline Fibroma & 16 & 1.3 & 10 & 0.8 & 6 & 0.5 & 62.5 vs $37.5 \%$ & $26-76$ & $41.6 \pm 18.2$ & $50.5 \pm 15.0$ & $44.9 \pm 17.1$ \\
\hline Osteoid osteoma & 17 & 1.4 & 8 & 0.7 & 9 & 0.7 & 47.1 vs $52.9 \%$ & $16-67$ & $31.2 \pm 22.3$ & $39.0 \pm 16.8$ & $34.6 \pm 19.8$ \\
\hline Osteochondroma & 46 & 3.8 & 28 & 2.3 & 18 & 1.5 & 60.9 vs $39.1 \%$ & $13-64$ & $34.0 \pm 16.6$ & $38.7 \pm 20.8$ & $36.1 \pm 18.4$ \\
\hline Solitary bone cyst & 25 & 2.1 & 8 & 0.7 & 17 & 1.4 & 32.0 vs $68.0 \%$ & $15-64$ & $29.5 \pm 15.2$ & $48.8 \pm 11.9$ & $41.1 \pm 16.2$ \\
\hline Lipoma & 7 & 0.6 & 5 & 0.4 & 2 & 0.2 & 71.4 vs $28.6 \%$ & $23-63$ & $41.8 \pm 16.5$ & $31.0 \pm 11.3$ & $38.7 \pm 15.2$ \\
\hline Aneurysmal bone cyst & 35 & 2.9 & 19 & 1.6 & 16 & 1.3 & 54.3 vs $45.7 \%$ & $10-62$ & $25 \pm 12.5$ & $36.4 \pm 15.3$ & $30.4 \pm 14.8$ \\
\hline Fibrous dysplasia & 4 & 0.3 & 2 & 0.2 & 2 & 0.2 & 50.0 vs $50.0 \%$ & $25-32$ & $29.5 \pm 3.5$ & $27 \pm 2.8$ & $28.3 \pm 3.0$ \\
\hline Malignant tumors & 429 & 35.5 & 286 & 23.7 & 143 & 11.8 & 66.7 vs $33.3 \%$ & $8-81$ & $48.3 \pm 16.7$ & $46.3 \pm 16.3$ & $47.4 \pm 16.5$ \\
\hline PNET/ Ewing's sarcoma & 17 & 1.4 & 9 & 0.7 & 8 & 0.7 & 52.9 vs $47.1 \%$ & $11-46$ & $26 \pm 13.3$ & $25.8 \pm 7.9$ & $25.9 \pm 10.9$ \\
\hline Chordoma & 119 & 9.8 & 79 & 6.5 & 40 & 3.3 & 66.4 vs $33.6 \%$ & $27-81$ & $56.6 \pm 15.0$ & $53.3 \pm 13.3$ & $55.5 \pm 14.1$ \\
\hline Malignant fibrous histiocytoma & 16 & 1.3 & 11 & 0.9 & 5 & 0.4 & 68.8 vs $31.2 \%$ & $29-67$ & $51 \pm 14.5$ & $50.7 \pm 1.9$ & $50.9 \pm 11.3$ \\
\hline Liposarcoma & 1 & 0.0 & 1 & 0.0 & 0 & 0.0 & NA & 44 & 44 & NA & 44 \\
\hline Osteosarcoma & 13 & 1.1 & 5 & 0.4 & 8 & 0.7 & 38.5 vs $61.5 \%$ & $14-60$ & $40.2 \pm 21.0$ & $25.8 \pm 11.7$ & $33.6 \pm 18.2$ \\
\hline Angiosarcoma & 10 & 0.8 & 7 & 0.6 & 3 & 0.2 & 70.0 vs $30.0 \%$ & $36-73$ & $54.3 \pm 11.3$ & $45.0 \pm 7.8$ & $51.5 \pm 10.9$ \\
\hline Malignant neurilemmoma & 30 & 2.5 & 15 & 1.2 & 15 & 1.2 & 50.0 vs $50.0 \%$ & $8-71$ & $40.4 \pm 16.3$ & $50.3 \pm 12.1$ & $45.3 \pm 15.0$ \\
\hline Plasma cell myeloma & 103 & 8.5 & 75 & 6.2 & 28 & 2.3 & 72.8 vs $27.2 \%$ & $10-76$ & $49.8 \pm 15.3$ & $57.2 \pm 12.6$ & $52.0 \pm 14.8$ \\
\hline Malignant lymphoma & 54 & 4.5 & 30 & 2.5 & 24 & 2.0 & 55.6 vs $44.4 \%$ & $10-77$ & $47.2 \pm 21.0$ & $46.5 \pm 18.7$ & $46.9 \pm 19.6$ \\
\hline Leiomyosarcoma & 1 & 0.0 & 1 & 0.0 & 0 & 0.0 & NA & 55 & 55 & NA & 55 \\
\hline Chondrosarcoma & 63 & 5.2 & 52 & 4.3 & 11 & 0.9 & 82.5 vs $17.5 \%$ & $20-68$ & $46.1 \pm 14.5$ & $37.3 \pm 14.8$ & $44.0 \pm 14.7$ \\
\hline Fibrosarcoma & 2 & 0.2 & 1 & 0.0 & 1 & 0.0 & 50.0 vs $50.0 \%$ & $30-61$ & 61 & 30 & $45.5 \pm 21.9$ \\
\hline Total & 1209 & 100 & 695 & 57.5 & 514 & 42.5 & 57.5 vs $42.5 \%$ & $8-81$ & $39.1 \pm 16.9$ & $39.6 \pm 16.7$ & $39.3 \pm 16.8$ \\
\hline
\end{tabular}



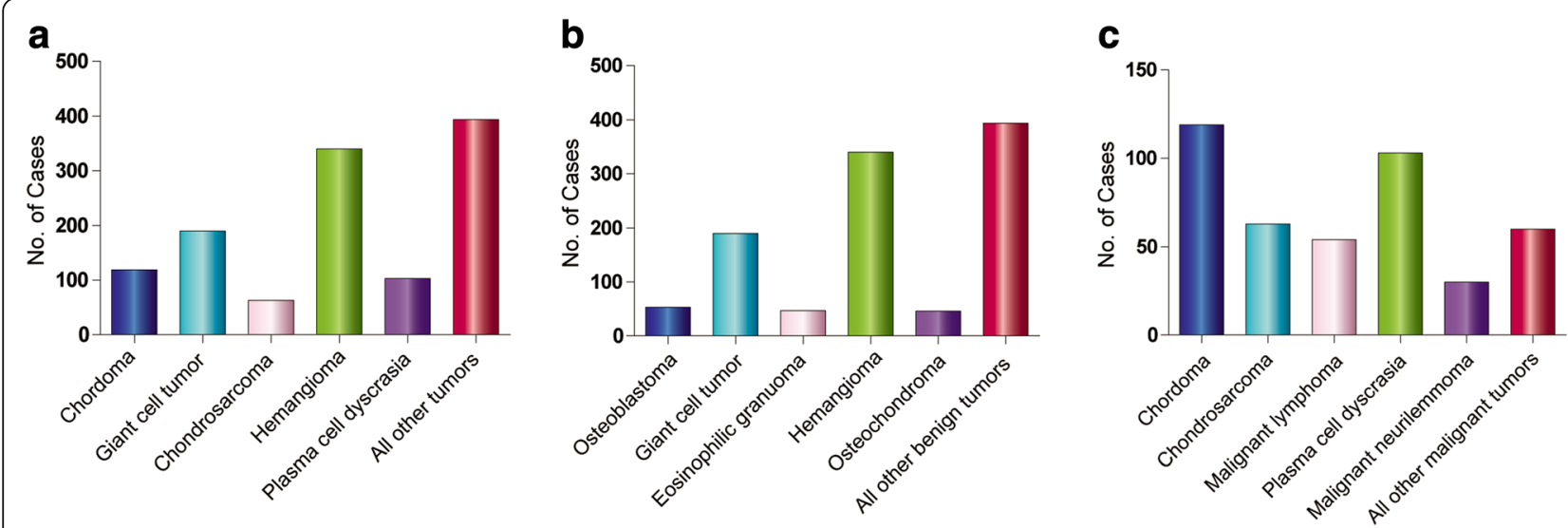

Fig. 1 Distribution of primary spine osseous tumors. Distribution of $\mathbf{a}$ all primary spine osseous tumor, $\mathbf{b}$ benign spine osseous, and $\mathbf{c}$ malignant spine osseous tumor cases by histological type

osteoblastoma (4.4\%; 53 cases), aneurysmal bone cyst (2.9\%; 35 cases), eosinophilic granuloma (3.9\%; 47 cases), osteochondroma (3.8\%; 46 cases), solitary bone cyst (2.1\%; 25 cases), osteoid osteoma $(1.4 \% ; 17$ cases $)$, fibroma (1.3\%; 16 cases), lipoma $(0.6 \%$; 7 cases), and fibrous dysplasia $(0.3 \% ; 4$ cases). Of malignant tumors, chordoma was the most common malignant tumor (9.8\% of all tumors, 119 cases), followed by plasma cell myeloma multiple myeloma (8.5\%,103 cases), chondrosarcoma (5.2\%, 63 cases), malignant lymphoma (4.5\%; 54 cases), malignant neurilemmoma $(2.5 \%$; 30 cases), primitive neural ectodermal tumor (PNET) \Ewing's sarcoma (1.4\%; 17 cases), malignant fibrous histiocytoma (1.3\%; 16 cases), osteosarcoma (1.1\%; 13 cases), and other sarcomas such as angiosarcoma, fibrosarcoma, liposarcoma, and leiomyosarcoma (less than 1\%).

Of the benign tumors, $20.5 \%$ were situated in the cervical spine, $26.1 \%$ in the thoracic spine, $12.0 \%$ in the lumbar spine, and $5.4 \%$ in the sacral spine. Of the malignant tumors, $6.9 \%$ were situated in the cervical spine, $12.0 \%$ in the thoracic spine, $6.3 \%$ in the lumbar spine, and $10.7 \%$ in the sacral spine. Of all tumors, $27.4 \%$ were situated in the cervical spine, $38.1 \%$ in the thoracic spine, $18.4 \%$ in the lumbar spine, and $16.1 \%$ in the sacral spine (Table 2).

In our series, most tumors with different histological types showed a similar distribution in males and females, although chordoma (119 cases, $\mathrm{M}: \mathrm{F}=2: 1$ ), plasma cell myeloma (103 cases, $\mathrm{M}: \mathrm{F}=2.7: 1)$, chondrosarcoma (63 cases, $\mathrm{M}: \mathrm{F}=4.7: 1$ ), and eosinophilic granuoma (47 cases, $\mathrm{M}: \mathrm{F}=3.3: 1)$ affected more frequently males than females (Table 3). From a total of 1209 bone tumors, the mean age (mean $\pm \mathrm{SD})$ was $39.3 \pm 16.8$ years (range, 881 years), $57.5 \%$ (695 cases) of the tumors occurred in males and $42.5 \%$ (514cases) in females, with a mean age (mean \pm SD) of $39.1 \pm 16.9$ and $39.6 \pm 16.7$ years. The mean age (mean $\pm \mathrm{SD}$ ) of benign tumors group was 34.7 \pm 19.8 years (range, $9-79$ years). Of 780 benign tumors, 409 cases (33.8\% of all cases) occurred in males and 371 cases $(30.7 \%$ of all cases) in females $(\mathrm{M}: \mathrm{F}=1.1: 1)$, with a mean age (mean \pm SD) of $33.7 \pm 19.2$ and $35.9 \pm$ 20.6 years. The mean age (mean $\pm \mathrm{SD}$ ) of malignant tumors group was $47.4 \pm 16.5$ years (range, $8-81$ years). Of 429 malignant tumors, 286 cases ( $23.7 \%$ of all cases) occurred in males and 143 cases (11.8\% of all cases) in females, with a mean age (mean \pm SD) of $48.3 \pm 16.7$ and $46.3 \pm 16.3$ years. The most commonly affected age group for benign tumors was the 31 - to 40 -year-old group $(14.3 \%$; 173 cases), followed by the 51 - to 60 -yearold group $(11.4 \% ; 138$ cases), and by the 41 - to 50 -yearold group (11.2\%; 136 cases). The most common age group affected by malignant bone tumors was the 41 - to 50 -year-old group (7.9\%; 95cases), followed by the 61 - to 70 -year-old group $(6.8 \% ; 82$ cases). A similar frequency was observed in the 31- to 40-year-old group (6.7\%; 81 cases) and the 51- to 60-year-old group $(6.5 \% ; 79$ cases).

As the most common presenting symptom, pain was found in 54.4\% (658/1209) of patients, affecting 35.0\% (273/780) of the benign and $89.7 \%$ (385/429) of the malignant tumors. Mass (swelling) was seen in 4.0\% (31/ 780 ) of benign tumors and $8.9 \%$ (38/429) of malignant tumors. One hundred fifty-six patients $(12.9 \%)$ had the symptoms of radiculopathy. Of all cases, 9.2\% (111/ 1209) of patients had signs of subtotal or complete cord compression. The cord compression symptoms included motor weakness $(8.2 \%, 99 / 1209)$, sphincter dysfunction $(0.7 \%, 8 / 1209)$, and paraplegia $(0.3 \%, 4 / 1209)$. Pathological fracture was found in 4.7\% (57/1209) of patients. Other symptoms included deformity $(2.1 \%, 25 / 1209)$ and weight loss $(1.9 \%, 23 / 1209)$ (Table 4$)$.

In our series, 398 cases with malignant tumors and 187 cases with benign tumors undergone surgery. Two hundred seventy-one cases with malignancies received 
Table 2 Distribution of spine osseous tumors by location

\begin{tabular}{|c|c|c|c|c|c|c|c|c|c|c|}
\hline \multirow[t]{2}{*}{ Type of tumor } & \multicolumn{2}{|c|}{ Cervical spine } & \multicolumn{2}{|c|}{ Thoracic spine } & \multicolumn{2}{|c|}{ Lumbar spine } & \multicolumn{2}{|c|}{ Sacral spine } & \multicolumn{2}{|l|}{ Totals } \\
\hline & No. & $\%$ & No. & $\%$ & No. & $\%$ & No. & $\%$ & No. & $\%$ \\
\hline Benign tumors & 257 & 20.5 & 328 & 26.1 & 151 & 12.0 & 68 & 5.4 & $804(780)^{a}$ & 64.0 \\
\hline Hemangioma & 104 & 8.3 & 149 & 11.7 & 86 & 6.8 & 11 & 0.9 & $350(340)^{a}$ & 27.9 \\
\hline Giant cell tumor & 44 & 3.5 & 87 & 6.9 & 23 & 1.8 & 36 & 2.9 & 190 & 15.1 \\
\hline Eosinophililc granuoma & 20 & 1.6 & 22 & 1.6 & 5 & 0.4 & 0 & 0.0 & 47 & 3.7 \\
\hline Osteoblastoma & 17 & 1.4 & 30 & 2.4 & 5 & 0.4 & 1 & 0.0 & 53 & 4.2 \\
\hline Fibroma & 17 & 1.4 & 5 & 0.4 & 5 & 0.4 & 3 & 0.2 & $30(16)$ & 2.4 \\
\hline Osteoid osteoma & 12 & 1.0 & 2 & 0.2 & 3 & 0.2 & 0 & 0.0 & 17 & 1.4 \\
\hline Osteochondroma & 21 & 1.7 & 12 & 1.0 & 11 & 0.9 & 2 & 0.2 & 46 & 3.7 \\
\hline Solitary bone cyst & 8 & 0.6 & 2 & 0.2 & 5 & 0.4 & 10 & 0.8 & 25 & 2.0 \\
\hline Lipoma & 5 & 0.4 & 1 & 0.0 & 0 & 0.0 & 1 & 0.0 & 7 & 0.6 \\
\hline Aneurysmal bone cyst & 9 & 0.7 & 16 & 1.3 & 6 & 0.5 & 4 & 0.3 & 35 & 2.8 \\
\hline Fibrous dysplasia & 0 & 0.0 & 2 & 0.2 & 2 & 0.2 & 0 & 0.0 & 4 & 0.3 \\
\hline Malignant tumors & 87 & 6.9 & 151 & 12.0 & 80 & 6.3 & 134 & 10.7 & $452(429)^{a}$ & 36.0 \\
\hline PNET/Ewing's sarcoma & 1 & 0.0 & 4 & 0.3 & 9 & 0.7 & 3 & 0.2 & 17 & 1.4 \\
\hline Chordoma & 29 & 2.3 & 5 & 0.4 & 5 & 0.4 & 80 & 6.4 & 119 & 9.5 \\
\hline Malignant fibrous histiocytoma & 0 & 0.0 & 8 & 0.6 & 3 & 0.2 & 5 & 0.4 & 16 & 1.3 \\
\hline Liposarcoma & 0 & 0.0 & 0 & 0.0 & 0 & 0.0 & 1 & 0.0 & 1 & 0.0 \\
\hline Osteosarcoma & 2 & 0.2 & 6 & 0.6 & 0 & 0.0 & 5 & 0.4 & 13 & 1.0 \\
\hline Angiosarcoma & 1 & 0.0 & 12 & 1.0 & 4 & 0.3 & 0 & 0.0 & $17(10)$ & 1.4 \\
\hline Malignant neurilemmoma & 4 & 0.3 & 4 & 0.3 & 12 & 1.0 & 12 & 1.0 & $32(30)^{a}$ & 2.5 \\
\hline Plasma cell myeloma & 27 & 2.1 & 50 & 4.0 & 26 & 2.1 & 9 & 0.7 & $112(103)$ & 8.9 \\
\hline Leiomyosarcoma & 0 & 0.0 & 0 & 0.0 & 0 & 0.0 & 1 & 0.0 & 1 & 0.0 \\
\hline Malignant lymphoma & 9 & 0.7 & 26 & 2.1 & 18 & 1.4 & 6 & 0.5 & $59(54)^{a}$ & 4.7 \\
\hline Chondrosarcoma & 14 & 1.1 & 36 & 2.9 & 2 & 0.2 & 11 & 0.9 & 63 & 5.0 \\
\hline Fibrosarcoma & 0 & 0.0 & 0 & 0.0 & 1 & 0.0 & 1 & 0.0 & 2 & 0.2 \\
\hline Total & 344 & 27.4 & 479 & 38.1 & 231 & 18.4 & 202 & 16.1 & $1256(1209)^{a}$ & 100 \\
\hline
\end{tabular}

${ }^{\mathrm{a}}$ More than two anatomical position involved in the same patient

chemotherapy. Thirty-four cases with malignant tumors were given radiotherapy. And other treatments were performed to 6 malignant cases and 35 benign cases respectively (Additional file 1: Table S1).

\section{Discussion}

Primary bone tumors of the spine are representing only less than $10 \%$ of all bone neoplasms. Available reports on the epidemiologic features of primary osseous spine tumors were mostly among Americans and Europeans [7-11]. To our knowledge, the present report represents epidemiologic features based the largest series of spinal osseous tumors from Asian. However, there are some differences of epidemiological characteristics in our study and previous reports (Table 5) [8, 10]. In Kelley's series [10], 23.02\% tumors were benign and $76.98 \%$ tumors were malignant, plasma cell myeloma was the most common primary malignant tumor, accounting for
$26 \%$, followed by chordoma (22.22\%) and osteosarcoma (9.52\%). Osteoblastoma (5.56\%) was the most common benign tumor, followed osteoclastoma $(0.79 \%)$ and aneurysmal bone cyst $(0.79 \%)$. In our series, benign tumors comprised $64.5 \%$ of primary tumors. The most frequent benign was hemangioma (28.1\%), followed by giant cell tumor (15.7\%) and osteoblastoma (4.4\%). The most frequent malignant was chordoma (9.8\%), followed by plasma cell myeloma (8.5\%) and chondrosarcoma (5.2\%). These findings were not consistent with results from previous studies based in Caucasian, which would be influenced by geographical and racial variations in different reports.

As the most frequent benign primary spine osseous tumor in present study, hemangioma was accounting for approximately one third of all primary tumors. During the past 20 years (1995-2015), 340 (28.1\% of all cases) cases of spinal hemangioma were diagnosed, and 350 
Table 3 Age distribution of patients with primary spine osseous tumors (years)

\begin{tabular}{|c|c|c|c|c|c|c|c|c|c|c|}
\hline \multirow[t]{2}{*}{ Type of tumor } & \multirow{2}{*}{$\begin{array}{l}0-10 \\
\text { No. (\%) }\end{array}$} & \multirow{2}{*}{$\begin{array}{l}11-20 \\
\text { No. (\%) }\end{array}$} & \multirow{2}{*}{$\begin{array}{l}21-30 \\
\text { No. (\%) }\end{array}$} & \multirow{2}{*}{$\begin{array}{l}31-40 \\
\text { No. (\%) }\end{array}$} & \multirow{2}{*}{$\begin{array}{l}41-50 \\
\text { №. (\%) }\end{array}$} & \multirow{2}{*}{$\begin{array}{l}51-60 \\
\text { No. (\%) }\end{array}$} & \multirow{2}{*}{$\begin{array}{l}61-70 \\
\text { No. (\%) }\end{array}$} & \multirow{2}{*}{$\begin{array}{l}71-80 \\
\text { No. (\%) }\end{array}$} & \multirow{2}{*}{$\begin{array}{l}81-90 \\
\text { No. (\%) }\end{array}$} & \multirow{2}{*}{$\begin{array}{l}\text { Total } \\
\text { no. (\%) }\end{array}$} \\
\hline & & & & & & & & & & \\
\hline Benign tumors & $14(1.2 \%)$ & 102(8.4\%) & $122(10.1 \%)$ & $173(14.3 \%)$ & $136(11.2 \%)$ & $138(11.4 \%)$ & $76(6.3 \%)$ & 19(1.6\%) & $0(0.0 \%)$ & $780(64.5 \%)$ \\
\hline Hemangioma & $1(0.0 \%)$ & $14(1.2 \%)$ & $18(1.5 \%)$ & $62(5.1 \%)$ & $78(6.5 \%)$ & $96(7.9 \%)$ & $53(4.4 \%)$ & $18(1.5 \%)$ & $0(0.0 \%)$ & $340(28.1 \%)$ \\
\hline Giant cell tumor & $0(0.0 \%)$ & $27(2.2 \%)$ & $50(4.1 \%)$ & $62(5.1 \%)$ & $32(2.6 \%)$ & $11(0.9 \%)$ & $8(0.7 \%)$ & $0(0.0 \%)$ & $0(0.0 \%)$ & 190(15.7\%) \\
\hline Eosinophililc granuloma & $3(0.2 \%)$ & 23(1.9\%) & $9(0.7 \%)$ & $5(0.4 \%)$ & $2(0.2 \%)$ & $5(0.4 \%)$ & $0(0.0 \%)$ & $0(0.0 \%)$ & $0(0.0 \%)$ & $47(3.9 \%)$ \\
\hline Osteoblastoma & $6(0.5 \%)$ & $11(0.9 \%)$ & $14(1.2 \%)$ & $11(0.9 \%)$ & $5(0.4 \%)$ & $6(0.5 \%)$ & $0(0.0 \%)$ & $0(0.0 \%)$ & $0(0.0 \%)$ & $53(4.4 \%)$ \\
\hline Fibroma & $0(0.0 \%)$ & $0(0.0 \%)$ & $4(0.3 \%)$ & $4(0.3 \%)$ & $2(0.2 \%)$ & $2(0.2 \%)$ & $3(0.2 \%)$ & $1(0.0 \%)$ & $0(0.0 \%)$ & 16(1.3\%) \\
\hline Osteoid osteoma & $0(0.0 \%)$ & $5(0.4 \%)$ & $3(0.2 \%)$ & $2(0.2 \%)$ & $2(0.2 \%)$ & $3(0.2 \%)$ & $2(0.2 \%)$ & $0(0.0 \%)$ & $0(0.0 \%)$ & $17(1.4 \%)$ \\
\hline Osteochondroma & $2(0.2 \%)$ & $12(1.0 \%)$ & $8(0.7 \%)$ & $9(0.7 \%)$ & $5(0.4 \%)$ & $5(0.4 \%)$ & $5(0.4 \%)$ & $0(0.0 \%)$ & $0(0.0 \%)$ & $46(3.8 \%)$ \\
\hline Solitary bone cyst & $0(0.0 \%)$ & $2(0.2 \%)$ & $3(0.2 \%)$ & $5(0.4 \%)$ & $6(0.5 \%)$ & $6(0.5 \%)$ & $3(0.2 \%)$ & $0(0.0 \%)$ & $0(0.0 \%)$ & $25(2.1 \%)$ \\
\hline Lipoma & $0(0.0 \%)$ & $0(0.0 \%)$ & $2(0.2 \%)$ & $3(0.2 \%)$ & $1(0.0 \%)$ & $1(0.0 \%)$ & $0(0.0 \%)$ & $0(0.0 \%)$ & $0(0.0 \%)$ & $7(0.6 \%)$ \\
\hline Aneurysmal bone cyst & $2(0.2 \%)$ & $8(0.7 \%)$ & $9(0.7 \%)$ & $8(0.7 \%)$ & $3(0.2 \%)$ & $3(0.2 \%)$ & $2(0.2 \%)$ & $0(0.0 \%)$ & $0(0.0 \%)$ & $35(2.9 \%)$ \\
\hline Fibrous dysplasia & $0(0.0 \%)$ & $0(0.0 \%)$ & $2(0.2 \%)$ & $2(0.2 \%)$ & $0(0.0 \%)$ & $0(0.0 \%)$ & $0(0.0 \%)$ & $0(0.0 \%)$ & $0(0.0 \%)$ & $4(0.3 \%)$ \\
\hline Malignant tumors & $5(0.4 \%)$ & $17(1.4 \%)$ & $36(3.0 \%)$ & $81(6.7 \%)$ & $95(7.9 \%)$ & $79(6.5 \%)$ & $82(6.8 \%)$ & $32(2.6 \%)$ & $2(0.2 \%)$ & $429(35.5 \%)$ \\
\hline PNET/Ewing's sarcoma & $0(0.0 \%)$ & $5(0.4 \%)$ & $7(0.6 \%)$ & $3(0.2 \%)$ & $2(0.2 \%)$ & $0(0.0 \%)$ & $0(0.0 \%)$ & $0(0.0 \%)$ & $0(0.0 \%)$ & $17(1.4 \%)$ \\
\hline Chordoma & $0(0.0 \%)$ & $0(0.0 \%)$ & $3(0.2 \%)$ & $17(1.4 \%)$ & $27(2.2 \%)$ & $23(1.9 \%)$ & $32(2.6 \%)$ & $15(1.2 \%)$ & $2(0.2 \%)$ & $119(9.8 \%)$ \\
\hline Malignant fibrous histiocytoma & $0(0.0 \%)$ & $0(0.0 \%)$ & $2(0.2 \%)$ & $0(0.0 \%)$ & $5(0.4 \%)$ & $6(0.5 \%)$ & $3(0.2 \%)$ & $0(0.0 \%)$ & $0(0.0 \%)$ & $16(1.3 \%)$ \\
\hline Liposarcoma & $0(0.0 \%)$ & $0(0.0 \%)$ & $0(0.0 \%)$ & $0(0.0 \%)$ & $1(0.0 \%)$ & $0(0.0 \%)$ & $0(0.0 \%)$ & $0(0.0 \%)$ & $0(0.0 \%)$ & $1(0.0 \%)$ \\
\hline Osteosarcoma & $0(0.0 \%)$ & $6(0.5 \%)$ & $2(0.2 \%)$ & $0(0.0 \%)$ & $3(0.2 \%)$ & $2(0.2 \%)$ & $0(0.0 \%)$ & $0(0.0 \%)$ & $0(0.0 \%)$ & $13(1.1 \%)$ \\
\hline Angiosarcoma & $0(0.0 \%)$ & $0(0.0 \%)$ & $0(0.0 \%)$ & $2(0.2 \%)$ & $3(0.2 \%)$ & $3(0.2 \%)$ & $1(0.0 \%)$ & $1(0.0 \%)$ & $0(0.0 \%)$ & $10(0.8 \%)$ \\
\hline Malignant neurilemmoma & $1(0.0 \%)$ & $1(0.0 \%)$ & $1(0.0 \%)$ & $9(0.7 \%)$ & $8(0.7 \%)$ & $5(0.4 \%)$ & $4(0.3 \%)$ & $1(0.0 \%)$ & $0(0.0 \%)$ & $30(2.5 \%)$ \\
\hline Plasma cell myeloma & $2(0.2 \%)$ & $0(0.0 \%)$ & $3(0.2 \%)$ & $17(1.4 \%)$ & $26(2.2 \%)$ & $22(1.8 \%)$ & $24(2.0 \%)$ & $9(0.7 \%)$ & $0(0.0 \%)$ & $103(8.5 \%)$ \\
\hline Leiomyosarcoma & $0(0.0 \%)$ & $0(0.0 \%)$ & $0(0.0 \%)$ & $0(0.0 \%)$ & $0(0.0 \%)$ & $1(0.0 \%)$ & $0(0.0 \%)$ & $0(0.0 \%)$ & $0(0.0 \%)$ & $1(0.0 \%)$ \\
\hline Malignant lymphoma & $2(0.2 \%)$ & $3(0.2 \%)$ & $6(0.5 \%)$ & $9(0.7 \%)$ & $12(1.0 \%)$ & $8(0.7 \%)$ & $8(0.7 \%)$ & $6(0.5 \%)$ & $0(0.0 \%)$ & $54(4.5 \%)$ \\
\hline Chondrosarcoma & $0(0.0 \%)$ & $2(0.2 \%)$ & $11(0.9 \%)$ & $24(2.0 \%)$ & $8(0.7 \%)$ & $9(0.7 \%)$ & $9(0.7 \%)$ & $0(0.0 \%)$ & $0(0.0 \%)$ & $63(5.2 \%)$ \\
\hline Fibrosarcoma & $0(0.0 \%)$ & $0(0.0 \%)$ & $1(0.0 \%)$ & $0(0.0 \%)$ & $0(0.0 \%)$ & $0(0.0 \%)$ & $1(0.0 \%)$ & $0(0.0 \%)$ & $0(0.0 \%)$ & $2(0.2 \%)$ \\
\hline Total & $19(1.6 \%)$ & $119(9.8 \%)$ & $158(13.1 \%)$ & $254(21.0 \%)$ & $231(19.1 \%)$ & $217(17.9 \%)$ & $158(13.1 \%)$ & $51(4.2 \%)$ & $2(0.2 \%)$ & 1209(100\%) \\
\hline
\end{tabular}

vertebrae were involved. This incidence of spinal hemangioma was significantly higher than that in other country [12], which suggested different epidemiologic features of spinal hemangioma in Asians. Giant cell tumor (GCT) of bone was considered a benign osteolytic tumor with variable aggressiveness and accounted for approximately $5 \%$ of all bone tumors $[4,13,14]$. In our study, GCTs accounted for $15.7 \%$ of spine osseous lesions, this incidence was markedly higher than that reported in other studies [15-19]. Almost of GCTs occurred in the second to fourth decades, with a slight female predilection $(\mathrm{M}: \mathrm{F}=1: 1.1)$ in the present series. The female predilection of GCT is supported by the earlier reports [17, 20-22]. Furthermore, GCTs also showed predilection for the thoracic vertebra of spine in our study, which is not in accordance with other reports $[19,23]$. Osteoblastoma was the third most common benign tumor in our study, with a relative frequency of 4.4\% which was higher compared with the previous report [24]. In Herman M. Kroon's and Richard A. Mcleod's reports [25, 26], osteoblastoma obviously affected more males than females (64:34 and 87:36 respectively). In our study, we only observed a slight male predilection ( $\mathrm{M}: \mathrm{F}=1: 1.1$ ). The most involved location was the thoracic spine, which is consistent with those reported from Europe and America [27, 28].

Chordoma was the most common malignant tumor which occurred more in males than in females in the present study. We found a significant predilection for males $(\mathrm{M}: \mathrm{F}=79: 40)$, in agreement with reports by $\mathrm{S}$ Boriani $(M: F=37: 15)$ [29], Silvia Stacchiotti $(M: F=91: 47)$ [30], and Johannm Bjornsson $(\mathrm{M}: \mathrm{F}=27: 13)$ [31]. It is worth noting that female preponderance $(17: 22)$ of chordoma was reported in Sweden [32]. In our series, chordomas were typically seen in adults and elderly, tended to occur in the sacrum $(9.5 \%, 119$ cases), which is consistent with the previous reports. In the present study, plasma cell myeloma accounted for $8.5 \%$ (103 cases) of 
Table 4 First presenting features when diagnosed with primary spine osseous tumors

\begin{tabular}{|c|c|c|c|c|c|c|c|c|c|c|}
\hline & $\begin{array}{l}\text { Total no. } \\
\text { of case }\end{array}$ & Pain & $\begin{array}{l}\text { Mass } \\
\text { (swelling) }\end{array}$ & Radiculopathy & $\begin{array}{l}\text { Motor } \\
\text { weakness }\end{array}$ & $\begin{array}{l}\text { Sphincter } \\
\text { dysfunction }\end{array}$ & Paraplegia & $\begin{array}{l}\text { Pathological } \\
\text { fracture }\end{array}$ & Deformity & $\begin{array}{l}\text { Weight } \\
\text { loss }\end{array}$ \\
\hline Benign tumors & 780 & $273(35.0 \%)$ & $31(4.0 \%)$ & $72(9.2 \%)$ & $45(5.8 \%)$ & 0 & 0 & $23(2.9 \%)$ & $4(0.5 \%)$ & $7(0.9 \%)$ \\
\hline Hemangioma & 340 & 18 & 2 & 1 & 0 & 0 & 0 & 0 & 0 & 1 \\
\hline Giant cell tumor & 190 & 169 & 11 & 65 & 43 & 0 & 0 & 21 & 3 & 2 \\
\hline $\begin{array}{l}\text { Eosinophililc } \\
\text { granuloma }\end{array}$ & 47 & 35 & 17 & 4 & 1 & 0 & 0 & 0 & 0 & 1 \\
\hline Osteoblastoma & 53 & 2 & 0 & 0 & 0 & 0 & 0 & 0 & 0 & 0 \\
\hline Fibroma & 16 & 4 & 0 & 0 & 0 & 0 & 0 & 0 & 0 & 0 \\
\hline Osteoid osteoma & 17 & 3 & 0 & 0 & 0 & 0 & 0 & 0 & 0 & 1 \\
\hline Osteochondroma & 46 & 13 & 0 & 0 & 0 & 0 & 0 & 0 & 0 & 1 \\
\hline $\begin{array}{l}\text { Solitary bone } \\
\text { cyst }\end{array}$ & 25 & 2 & 1 & 0 & 0 & 0 & 0 & 0 & 0 & 0 \\
\hline Lipoma & 7 & 0 & 0 & 0 & 0 & 0 & 0 & 0 & 0 & 0 \\
\hline $\begin{array}{l}\text { Aneurysmal bone } \\
\text { cyst }\end{array}$ & 35 & 25 & 0 & 1 & 1 & 0 & 0 & 1 & 0 & 1 \\
\hline Fibrous dysplasia & 4 & 2 & 0 & 1 & 0 & 0 & 0 & 1 & 1 & 0 \\
\hline $\begin{array}{l}\text { Malignant } \\
\text { tumors }\end{array}$ & 429 & $385(89.7 \%)$ & $38(8.9 \%)$ & $84(19.9 \%)$ & $54(12.6 \%)$ & $8(1.9 \%)$ & $4(0.9 \%)$ & $34(7.9 \%)$ & $21(4.9 \%)$ & $16(3.7 \%)$ \\
\hline $\begin{array}{l}\text { PNET/Ewing's } \\
\text { sarcoma }\end{array}$ & 17 & 16 & 1 & 0 & 0 & 0 & 0 & 1 & 0 & 0 \\
\hline Chordoma & 119 & 101 & 15 & 43 & 35 & 7 & 2 & 12 & 6 & 3 \\
\hline $\begin{array}{l}\text { Malignant } \\
\text { fibrous } \\
\text { histiocytoma }\end{array}$ & 16 & 13 & 10 & 0 & 0 & 0 & 0 & 1 & 0 & 0 \\
\hline Liposarcoma & 1 & 1 & 0 & 1 & 0 & 0 & 0 & 1 & 0 & 0 \\
\hline Osteosarcoma & 13 & 13 & 2 & & 0 & 0 & 0 & 0 & 0 & 0 \\
\hline Angiosarcoma & 10 & 9 & 1 & 1 & 0 & 0 & 0 & 0 & 0 & 0 \\
\hline $\begin{array}{l}\text { Malignant } \\
\text { neurilemmoma }\end{array}$ & 30 & 28 & 0 & 28 & 15 & 1 & 0 & 0 & 0 & 0 \\
\hline $\begin{array}{l}\text { Plasma cell } \\
\text { myeloma }\end{array}$ & 103 & 92 & 0 & 7 & 2 & 2 & 2 & 19 & 15 & 13 \\
\hline Leiomyosarcoma & 54 & 51 & 7 & 3 & 1 & 0 & 0 & 0 & 0 & 0 \\
\hline $\begin{array}{l}\text { Malignant } \\
\text { lymphoma }\end{array}$ & 1 & 1 & 0 & 0 & 0 & 0 & 0 & 0 & 0 & 0 \\
\hline Chondrosarcoma & 63 & 58 & 0 & 0 & 0 & 0 & 0 & 0 & 0 & 0 \\
\hline Fibrosarcoma & 2 & 2 & 2 & 1 & 1 & 0 & 0 & 0 & 0 & 0 \\
\hline Total & 1209 & 658(54.4\%) & $69(5.7 \%)$ & 156(12.9\%) & $99(8.2 \%)$ & $8(0.7 \%)$ & $4(0.3 \%)$ & $57(4.7 \%)$ & $25(2.1 \%)$ & $23(1.9 \%)$ \\
\hline
\end{tabular}

all cases, representing the second most frequent primary malignant osseous tumor of spine, and often occurring in thoracic spine (4.0\%, 50 vertebrae were involved). All plasma cell myeloma cases were found in the 4th-7th decade of life with a male predominance $(\mathrm{M}: \mathrm{F}=2.7: 1)$. Previous studies reported that chondrosarcoma accounted for $3-12 \%$ of all spine primary tumors [33-36]. In S Boriani's report, the lumbar spine was the most frequently involved location $(15 / 22,68 \%)$ [33]. However, in the present study, thoracic spine was the most common location involved with chondrosarcoma $(2.9 \%, 36$ cases), and only 2 cases were observed in the lumbar spine. Most patients commonly encountered chondrosarcoma after the age of 20 , with a great male predilection $(\mathrm{M}: \mathrm{F}=4.7: 1)$.

Surgery is the first choice for the pain and neurological symptoms caused by spine tumors. Surgery can completely or partly alleviate tumor compression to the spinal cord, establish a tumor-free solid spine and relieve pain. In primary malignant tumors of the spine, total/partial laminectomy, total/partial vertebral body resection, and piecemeal resection and curettage, in addition to the surgical procedures described above, can be used. Chemotherapy and radiotherapy 
Table 5 World literature of population-based studies on the epidemiology of primary spine osseous tumor

\begin{tabular}{llll}
\hline & This study & Simon P. Kelley & S. Boriani \\
\hline Author's country & China & UK & Italy \\
Year of publication & 2016 & 2007 & 1995 \\
Period of study & $1995-2015$ (20 years) & $1958-2000$ (42 years) & $1946-1992$ (46 years) \\
No. of cases & 1209 & 127 & 366 \\
Gender & Male: 695 Female:514 & Male: 66 Female:61 & Not reported \\
Predominant presenting symptom & Pain & Pain & Not reported \\
Percentage of benign tumors & $64.5 \%$ & $22.8 \%$ & $56.8 \%$ \\
Percentage of malignant tumors & $35.5 \%$ & $77.2 \%$ & $43.2 \%$ \\
Most common type of benign tumors & Hemangioma & Eosinophilic granuloma \\
Most common type of malignant tumors & Chordoma & Plasma cell myeloma & Plasma cell myeloma \\
Most common segment of spine affected & Thoracic spine (479/1256) & Thoracic spine (48/127) & Lumbar spine (181/366) \\
Mean age at presentation (range) & $39.3 \pm 16.8$ (range 8-81 years) & 42 (range 7-76 years) & Not reported \\
\hline
\end{tabular}

${ }^{a}$ More than two anatomical position involved in the same patient

after surgery were used to reduce the risk of the cancer relapse or shrinks some malignant tumor such Ewing's sarcoma that cannot be completely removed with surgery. Many benign silent (no symptom) tumors such as hemangioma were found in health checkup, and most of them did not receive any treatment. Although the WHO defines GCT as a benign osteolytic neoplasm, GCT displays the characteristics of both malignant and benign tumors and actually represents a benign tumor with the potential of malignancy [37-39]. In our series, most cases of GCT undergone total spondylectomy, vertebrectomy, piecemeal resection or curettage. Some cases of GCT received other therapy such as bisphosphonate treatment after surgery.

\section{Conclusions}

Our study results represent data on the epidemiology of spinal osseous tumors in a large population of patients. We think that these data may reflect the epidemiological features of spine osseous tumors in Eastern China. For geographical and racial variations, the incidence of these neoplasms in a developing country is partly different from that found in other countries. There were several limitations in this study. As medical imaging technology have improved greatly during the study time span, the diagnosis sensitivity of primary spinal osseous tumors should lead to different prevalence in different time. Although the prognosis of spinal osseous tumors and longitudinal changes could not be fully assessed due to the nature of a retrospective study, we hope our work could provide useful epidemiological information as these data may have important implications for public health programs.

\section{Additional files}

Additional file 1: Table S1. Treatment of primary spine osseous tumor. (DOCX $14 \mathrm{~kb}$ )

\section{Acknowledgements \\ Not applicable. \\ Funding \\ The study was funded by the Bone Tumors and Nervous System Tumors Biobank Project of Shanghai (12DZ2295103), Bone Tumor Sample Databases and Digital Information Platform Project of Shanghai (08DZ2292800), and Shanghai Biobank Network of Common Human Tumor Tissue (12DZ2295100).}

\section{Availability of data and materials}

The manuscript does not refer to any new software, application, or tool. The authors do not wish to share data analyzed in this manuscript as no such consent was provided by the patients treated and no approval of the Bioethics Committee was obtained.

\section{Authors' contributions}

ZZ wrote the manuscript. ZZ and XW performed data analysis. ZW and WH collected and evaluated information of cases. JX conceived of the study and participated in its designation. All authors read and approved the final manuscript.

\section{Competing interests}

The authors declare that they have no competing interests.

\section{Consent for publication}

Not applicable.

Ethics approval and consent to participate

All procedures performed in studies involving human participants were in accordance with the ethical standards of the Clinical Research Ethics

Committee of Second Military Medical University and with the 1964 Helsinki declaration and its later amendments or comparable ethical standards. Human data were obtained with informed consent, and this study was approved by the Clinical Research Ethics Committee of the Second Military Medical University. 


\section{Publisher's Note}

Springer Nature remains neutral with regard to jurisdictional claims in published maps and institutional affiliations.

Received: 25 September 2016 Accepted: 22 March 2017

Published online: 04 April 2017

\section{References}

1. Polednak AP. Primary bone cancer incidence in black and white residents of New York State. Cancer. 1985;55:2883-8.

2. Yeole BB, Jussawalla DJ. Descriptive epidemiology of bone cancer in greater Bombay. Indian J Cancer. 1998;35:101-6.

3. Barbosa CS, Araujo AB, Miranda D. Incidence of primary benign and malignant neoplasms and bone pseudotumoral lesions. An epidemiologic analysis of 585 cases diagnosed at the Faculdade de Medicina of the Universidade Federal de Minas Gerais. AMB Rev Assoc Med Bras. 1991;37:187-92.

4. Baena-Ocampo Ldel C, Ramirez-Perez E, Linares-Gonzalez LM, DelgadoChavez R. Epidemiology of bone tumors in Mexico City: retrospective clinicopathologic study of 566 patients at a referral institution. Ann Diagn Pathol. 2009:13:16-21.

5. Ciftdemir M, Kaya M, Selcuk E, Yalniz E. Tumors of the spine. World J Orthop. 2016;7:109-16.

6. Fletcher CDM UK, Fletcher F, editors. World Health Organization classification of tumors. Pathology and genetics of tumors of soft tissue and bone. Lyon: IARC Press; 2013.

7. Chi JH, Bydon A, Hsieh P, Witham T, Wolinsky JP, Gokaslan ZL. Epidemiology and demographics for primary vertebral tumors. Neurosurg Clin N Am. 2008;19:1-4.

8. Boriani S, Biagini R, De lure F, Andreoli I, Campanacci L, De Fiore M, Zanoni A. Primary bone tumors of the spine: a survey of the evaluation and treatment at the Istituto Ortopedico Rizzoli. Orthopedics. 1995;18:993-1000.

9. Benezech J, Fuentes JM. Primary tumors of the spine. A multicenter cooperative study. Neurochirurgie. 1989:35:317-22.

10. Kelley SP, Ashford RU, Rao AS, Dickson RA. Primary bone tumours of the spine: a 42-year survey from the Leeds Regional Bone Tumour Registry. Eur Spine J. 2007;16:405-9.

11. Dreghorn CR, Newman RJ, Hardy GJ, Dickson RA. Primary tumors of the axial skeleton. Experience of the Leeds Regional Bone Tumor Registry. Spine (Phila Pa 1976). 1990;15:137-40.

12. Doppman JL, Oldfield EH, Heiss JD. Symptomatic vertebral hemangiomas: treatment by means of direct intralesional injection of ethanol. Radiology. 2000;214:341-8.

13. Gupta R, Seethalakshmi V, Jambhekar NA, Prabhudesai S, Merchant N, Puri A, Agarwal M. Clinicopathologic profile of 470 giant cell tumors of bone from a cancer hospital in western India. Ann Diagn Pathol. 2008;12:239-48.

14. Goldenberg RR, Campbell CJ, Bonfiglio M. Giant-cell tumor of bone. An analysis of two hundred and eighteen cases. J Bone Joint Surg Am. 1970:52:619-64.

15. Sanjay BK, Sim FH, Unni KK, McLeod RA, Klassen RA. Giant-cell tumours of the spine. J Bone Joint Surg (Br). 1993;75:148-54.

16. Balke M, Schremper L, Gebert C, Ahrens H, Streitbuerger A, Koehler G, Hardes J, Gosheger G. Giant cell tumor of bone: treatment and outcome of 214 cases. J Cancer Res Clin Oncol. 2008;134:969-78.

17. Campanacci M, Baldini N, Boriani S, Sudanese A. Giant-cell tumor of bone. J Bone Joint Surg Am. 1987:69:106-14.

18. Luther N, Bilsky MH, Hartl R. Giant cell tumor of the spine. Neurosurg Clin N Am. 2008:19:49-55.

19. Leggon RE, Zlotecki R, Reith J, Scarborough MT. Giant cell tumor of the pelvis and sacrum: 17 cases and analysis of the literature. Clin Orthop Relat Res 2004:423:196-207.

20. Zhen W, Yaotian H, Songjian L, Ge L, Qingliang W. Giant-cell tumour of bone. The long-term results of treatment by curettage and bone graft. J Bone Joint Surg (Br). 2004;86:212-6.

21. Olivera P, Perez E, Ortega A, Terual R, Gomes C, Moreno LF, Duenas A, De La Garza J, Melendez-Zajgla J, Maldonado V. Estrogen receptor expression in giant cell tumors of the bone. Hum Pathol. 2002;33:165-9.

22. Saiz P, Virkus W, Piasecki P, Templeton A, Shott S, Gitelis S. Results of giant cell tumor of bone treated with intralesional excision. Clin Orthop Relat Res. 2004;424:221-6.

23. Ozaki T, Liljenqvist U, Halm H, Hillmann A, Gosheger G, Winkelmann W. Giant cell tumor of the spine. Clin Orthop Relat Res. 2002;401:194-201.
24. Dahlin DC. Bone tumors: general aspects and an analysis of 3987 cases. Second edition. Springfield, Illinois: Charles C Thomas, Pbulisher; 1967.

25. Kroon HM, Schurmans J. Osteoblastoma: clinical and radiologic findings in 98 new cases. Radiology. 1990;175:783-90.

26. McLeod RA, Dahlin DC, Beabout JW. The spectrum of osteoblastoma. AJR Am J Roentgenol. 1976;126:321-5.

27. Kirwan EO, Hutton PA, Pozo JL, Ransford AO. Osteoid osteoma and benign osteoblastoma of the spine. Clinical presentation and treatment. J Bone Joint Surg (Br). 1984;66:21-6.

28. MacLellan DI, Wilson Jr FC. Osteoid osteoma of the spine. A review of the literature and report of six new cases. J Bone Joint Surg Am. 1967:49:111-21.

29. Boriani S, Bandiera S, Biagini R, Bacchini P, Boriani L, Cappuccio M, Chevalley F, Gasbarrini A, Picci P, Weinstein JN. Chordoma of the mobile spine: fifty years of experience. Spine (Phila Pa 1976). 2006;31:493-503.

30. Stacchiotti S, Casali PG, Lo Vullo S, Mariani L, Palassini E, Mercuri M, Alberghini M, Pilotti S, Zanella L, Gronchi A, Picci P. Chordoma of the mobile spine and sacrum: a retrospective analysis of a series of patients surgically treated at two referral centers. Ann Surg Oncol. 2010;17:211-9.

31. Bjornsson J, Wold LE, Ebersold MJ, Laws ER. Chordoma of the mobile spine. A clinicopathologic analysis of 40 patients. Cancer. 1993;71:735-40.

32. Bergh P, Kindblom LG, Gunterberg B, Remotti F, Ryd W, Meis-Kindblom JM. Prognostic factors in chordoma of the sacrum and mobile spine: a study of 39 patients. Cancer. 2000;88:2122-34.

33. Boriani S, De lure F, Bandiera S, Campanacci L, Biagini R, Di Fiore M Bandello L, Picci P, Bacchini P. Chondrosarcoma of the mobile spine: report on 22 cases. Spine (Phila Pa 1976). 2000:25:804-12.

34. Camins MB, Duncan AW, Smith J, Marcove RC. Chondrosarcoma of the spine. Spine (Phila Pa 1976). 1978;3:202-9.

35. Kaim AH, Hugli R, Bonel HM, Jundt G. Chondroblastoma and clear cell chondrosarcoma: radiological and MRI characteristics with histopathological correlation. Skeletal Radiol. 2002:31:88-95.

36. Resnick DKM, Greenway GD. Tumors and tumor-like lesions of bone: imaging and pathology of specific lesions. In: Resnick D, editor. Diagnosis of bone and joint disorders. Philadelphia: Saunders; 2002. p. 3897.

37. Chakarun CJ, Forrester DM, Gottsegen CJ, Patel DB, White EA, Matcuk Jr GR Giant cell tumor of bone: review, mimics, and new developments in treatment. Radiographics. 2013:33:197-211.

38. Raskin KA, Schwab JH, Mankin HJ, Springfield DS, Hornicek FJ. Giant cell tumor of bone. J Am Acad Orthop Surg. 2013:21:118-26.

39. Cowan RW, Singh G. Giant cell tumor of bone: a basic science perspective. Bone. 2013:52:238-46.

\section{Submit your next manuscript to BioMed Central and we will help you at every step:}

- We accept pre-submission inquiries

- Our selector tool helps you to find the most relevant journal

- We provide round the clock customer support

- Convenient online submission

- Thorough peer review

- Inclusion in PubMed and all major indexing services

- Maximum visibility for your research

Submit your manuscript at www.biomedcentral.com/submit 